\title{
Tatyana Rozhdestvenskaya
}

Saint Petersburg State University, Russia

tat.rozhd@gmail.com

\section{Liturgical text in the Epigraphy of Old Rus'}

The paper analyses the linguistic aspect of biblical and liturgical quotations in the wall-inscriptions (graffiti) of the $12^{\text {th }}-15^{\text {th }}$ centuries in the Churches of Old Rus'. Paleografic, orthographic and textual features of the liturgical graffiti characterize them as texts, reflecting both the norms of the Church Slavonic language in Russia and its regional variants, as well as features associated with the oral form of their existence.

Keywords: medieval biblical and liturgical church wall-inscriptions Old Rus', the oral stage of the existence of canonical texts

\section{Франческа Ромоли}

DOI: $10.31168 / 91674-576-4.29$

Университет г. Пизы, Италия

francesca.romoli@unipi.it

\section{Житие Антония Римлянина: от местного к общему}

Доклад посвящен исследованию Жития Антония Римлянина в контексте средневековой восточнославянской агиографической традиции. Исследование проводится на уровне морфологии текста, метода его создания, идеологического замысла, культурно-исторических условий его появления и последующего развития.

Ключевые слова: Антоний Римлянин, церковнославянская литература, восточнославянская агиография.

Житие Антония Римлянина сохранилось в рукописях в двух вариантах единственной редакции. Первый вари- 
ант относится к эпохе, когда установили местное почитание святого, а второй к периоду, когда процесс утверждения его культа завершился. Первый вариант описывает жизнь святого от рождения до смерти, второй вариант дополняет биографическое повествование предисловием и сведениями об обретении мощей и чудесах.

По содержанию, присутствию/отсутствию и последовательности в ней традиционных элементов и тем, биография святого отдаляется от агиографического канона. Автор доклада выдвигает предположение о том, что морфологическая специфика Жития связана с методом создания текста, на который повлияли культурные условия его появления, а именно желание уравнять в достоинстве Великий Новгород, потерявший свою политическую независимость, с Москвой-третьим Римом.

Житие разделяет свое своеобразие и судьбу с другими произведениями Новгородской и Ростовской агиографии. Составленные с помощью одинаковых композиционных приёмов, основанных на слиянии предшествующих материалов с целью сопротивляться московской идеологии и централизации, эти произведения сливались в общерусскую агиографическую традицию, при включении в которую подвергались стандартизации, результатом чего и является второй вариант текста.

\section{Francesca Romoli}

University of Pisa, Italy

francesca.romoli@unipi.it

\section{The Life of Antonij Rimljanin: from local to widespread veneration}

The paper aims at investigating the Life of Antonij Rimljanin in the context of East Slavic medieval hagiography. Investigation of the text is undertaken at the level of morphology, method of composition, ideological 
meaning, the historical and cultural context of its genesis and subsequent development.

Key words: Antonij Rimljanin, Church Slavonic Literature, East Slavic Hagiography

Ольга Савельева

DOI: $10.31168 / 91674-576-4.30$

Московский государственный университет имени

М.В.Ломоносова, Россия

dus.177@gmail.com

\section{Рефлексия образа «тишины»}

в русской словесности XVIIІв.: Ломоносов и Пиндар

Рассматривается содержание художественно-философского образа «тишины» в русской словесности XVIII в. Образ «Возлюбленная Тишина» и общий стиль оды М.В. Ломоносова (1747 г.) может быть связан с ранней греческой одической поэтикой (Пиндар. Пифийская 8).

Ключевые слова: образ «тишины», Ломоносов, Пиндар, одическая поэтика

1. Идея «тишины», как художественно-философский образ, оказалась востребованной в европейской культуре Нового времени. История, содержание образа отличаются многоплановостью, его истоки связывают с древнеиндийскими толкованиями «ясности, прозрачности», позже в философии, эстетике «тишина» объединяется с «покоем, созерцательностью, светом», с «абсолютно положительным видением мира», сближается с категорией Возвышенного, которая обращает нас к описаниям позднеантичных риторов (Псевдо-Лонгин). В Новое время, категориально разработанная в немецкой и французской эстетике XVII в., в русский культурный дискурс она была введена М.В. Ломоносовым, В.К. Тредиаковским, получила богатое раз- 